\title{
Health effects of air pollution in Canada: Expert panel findings for The Canadian Smog Advisory Program
}

\author{
DAVID M STIEB ${ }^{\star \dagger}$ MD MSc CCFP FRCPC, L DAVID PENGELLY ${ }^{\dagger \ddagger}$ PhD, NINA ARRON* BScPHN MHA, \\ $S$ MARTIN TAYLOR ${ }^{\dagger \S}$ PhD, MARK E RAIZENNE* BSc \\ *Air Quality Health Effects Research Section, Health Canada, Ottawa, 'Institute of \\ Environment and Health, McMaster University and University of Toronto, ${ }^{\ddagger}$ Departments of \\ Medicine and Engineering Physics, McMaster University, Hamilton, ${ }^{\S}$ Department of \\ Geography, McMaster University, Hamilton, Ontario
}

DM Stieb, LD PEngelly, N ARron, SM TAYlor, ME RAIZENNE. Health effects of air pollution in Canada: Expert panel findings for The Canadian Smog Advisory Program. Can Respir J 1995;2(3):155-160.

Oв.JECTIVE: To review the evidence on health effects of air pollution for the Canadian Smog Advisory Program.

Methods: Evidence wats teviewed by wo expert panels, who were asked to define the health effects expected at levels of exposure given by the Nationat Ambient Air Quality Objectives, to examine a variety of issues related to communicating with the public about cnvirommental health risks, and to draft health messages for the advisory program. RESULTS: The panels concluded that health effects of ground-level orone at levels that oceur in Canada include pulmonary inflammation, pulmonary function decrements, airwaly hyperreactivity, respiratory synptoms, possible increased medication use and physician/emergency room vis- its among individuals with heart or lung discalse, reduced exercise capacity, increased hospital admissions and possible increased mortality. Similar effects were felt to occur in association with airborne particles, with the exception of inflanmatory changes, and with the addition of increased school absenteeism. Poor data on individual exposure were identified as a limitation of studies on hospital admissions and mortality.

Recommendations: The panels identified the need to reflect the evidence accurately without unduly raising public concern and recommended that advisory health messages identify expected health effects, while health care providers could more appropriately recommend protective actions to individuals. Supplementary educational stratcgies and evaluation of the advisory program were also recommended. (Pout lo risumé, verir purse' 156 )

Key Words: Advisoric's, Air pollutiom, ()=one. Simose

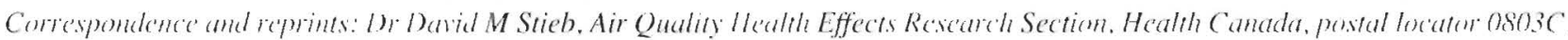

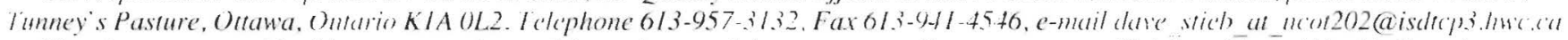

The views expressed in this pruper are those of the authors und do not necessarily represent an official position of llealth Canatu

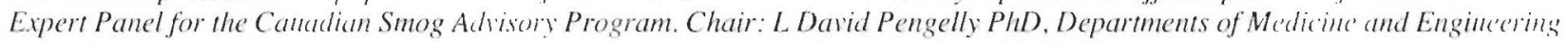
Physics. MCMaster Universits: Panel memlers: David V Bates MD FRCP FRCPC FACP FRSC. Departme'mt of Ilealth Care and Epidemiology, University of British Cohmbia; Mark Frampton MD, Departments of Medicine and Envirommentul Medicine. Uhiversity of Rochester: Teresa M McGrath MD. Onturio Ministry of Labour; Andrew D Oxman MD MSC FRCPC. Deparments of Clinical

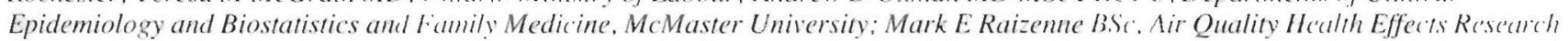
Section. Health Canada: Lou Sthenfeld Mi PEng. The MEP Company; Frances Silverman PhD, I) ('partment of Medicine. Unilersity of

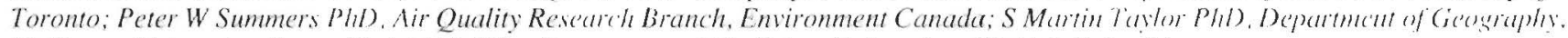
McMaster Univerits: Sieme Vedal MD MSi, Deparment of Medicine. University of British Columbia 


\section{Effets sur la santé de la pollution atmosphéri- que au Canada : Résultats rapportés par un groupe d'experts pour le Programme ca- nadien d'avertissement de smog}

\begin{abstract}
OBJectif : Passer en revue les preuves des effets sur la santé de la pollution at mosphéricuce pour le Programme canadien d'avertissement de smog.

MÉTHODEs : Les preuves ont été examinées par deux groupes d'experts à qui l'on a demandé de déterminer les effets attendus sur la santé à des niveaux d'exposition fournis par les objectifs nationaux afférents à la qualité de l'air ambiant, d'examiner une variété de questions ayant trait à l'information de la population sur les risques environnementaux pour la santé, et d'ébaucher des messages sanitaires pour le Programme d'avertissement.

RÉSULTATS : Les groupes d'experts ont conclu que les effets sur la santé de l'ozone au ras du sol à des niveaux détectés au Canada comprennent notamment l'inflammation pulmonaire, la détérioration de la fonction pulmonaire, l'hyperréactivité bronchique, des symptomes respiratoires, une augmentation possible
\end{abstract}

kc l'utilisation des médicaments et des consultations a l'urgence ou chez le médecin parmi les individus souffrant d'une affection pulmonaire ou cardiaque, une tolérance réduite à l'exercice, une augmentation des hospitalisations et augmentation possible de la mortalité. On pense que des effets similaires se produisent en association avec les particules aérogènes, à l'exception des changements inflammatoires, et en y ajoutant une augmentation de l'absentéisme scolaire. Des données insuffisantes sur l'exposition individuelle ont été identifiées comme une limitation des études sur les hospitalisations et la mortalité.

RECommandations : Les experts ont identifié le besoin de refléter correctement les preuves sans trop soulever d'inquiétudes dans la population et ont recommandé que les messages-santé identifient les effets attendus sur la santé, pendant que les pourvoyeurs des soins de santé pourraient plus adéquatement recommander des comportements protecteurs aux individus. Des stratégies éducatives supplémentaires et une évaluation du Programme d'avertissement ont aussi été reconmandées.

Pour obtenir la version française intégrale de cr't article' commmuniquez avec l'auteur à l'adresse indiquée.
$\mathrm{T}$ HE TERM 'SMOG' $\because$ IIAS BEEN USED IN NORTH AMERIC'A to describe a characteristic form of air pollution that generally occurs from late spring to early fall. Smog was recognized as a Canadian pollution issue in the federal 'Green Plan' in 1990, and in 1993 Environment Canada introduced the Canadian Smog Advisory Program. This report presents background information on air pollution in Canada and summarizes the findings of an expert panel process undertaken in support of the Canadian Smog Advisory Program. It is a condensed and modified version of the original report on the panel process (1). Its purpose is to provide clinicians and public health workers with the information needed to respond appropriately to questions or concerms of patients and members of the public that may be triggered by snog advisorics.

\section{BACKGROUND}

Although air quality in Canada has generally improved over the past 15 years, smog episodes still occur. These episodes, which are primarily a summer phenomenon, consist principally of elevated concentrations of ground-level orone, although acid aerosols (at type of airborne particle) may also be present (2). A different form of smog, "winter smog', may also occur, whose principal constituents are sulphur dioxide and airborne particles (including acid aerosols) (2). Ground-level ozone and airbornc particles were the focus of the panel process.

Ground-level ("tropospheric') ozone, which should be distinguished from stratospheric ozone ("the ozone layer"), is a gas that is formed when its precursors, oxides of nitrogen and hydrocarbons, interact in the atmosphere in the presence of high temperatures and sunlight (3). Smog and its precursors may be transported long distances through the atmosphere (3) with the result that high concentrations of ground-level ozone may be found in both rural and urban areas (4). Although long range transport contributes significantly to ob- served ground-level ozone concentrations in a number of regions, its impact is particularly apparent in Atlantic Canada, where peak concentrations may occur at night. In most other areas, peaks occur during the late afternoon and early evening in the summer months. In Canada, the current National Ambient Air Quality Objective for ground-level ozone ( $1 \mathrm{~h}$ maximum of 82 parts per billion [ppb] - maximum acceptable concentration) is exceeded most often in southern Ontario, southern Quebec, Vancouver and southern New Brunswick (5) (Figure 1).

Airborne particles are very small pieces of solid or liquid matter, which vary in size, chemical composition and source. Smaller particles, which have the greatest health significance, tend to arise from man-made sources, particularly fuel combustion, and include acid aerosols such as sulphates and nitrates, as well as metal oxides (6). Larger particles consist mainly of naturally occurring substances, particularly soil (6). Particles less than $10 \mu \mathrm{m}$ in diameter $\left(\mathrm{PM}_{10}\right)$ are consiclered 'inhalable' (7). The current National Ambient Air Quality Objective for total suspended particles (TSP - airborne particles of all sizes) is $120 \mu \mathrm{g} / \mathrm{m}^{3}$ for $24 \mathrm{~h}$ concentration, which is still exceeded at least $10 \%$ of the time in some cities across Canada (5). The current US standard for $\mathrm{PM}_{10}$ is 150 $\mu \mathrm{g} / \mathrm{m}^{3}$ for $24 \mathrm{~h}$ concentration. Recent data reveal $24 \mathrm{~h}$ concentrations that exceed $100 \mu \mathrm{g} / \mathrm{m}^{3}$ in a number of Canadian cities (8). Health Canada is currently developing a Canadian PM10 objective.

The Smog Advisory Program was introduced in the summer of 1993 under Canada's Green Plan as a means of informing the public about both environmental and health aspects of smog episodes. The program was first implemented in Saint John, New Brunswick, in southern Ontario and in the Greater Vancouver Regional District, and began in Montreal in 1994. As described earlier, these areas are situated in the geographic regions in which the highest groundlevel ozone concentrations have been observed. Under the 


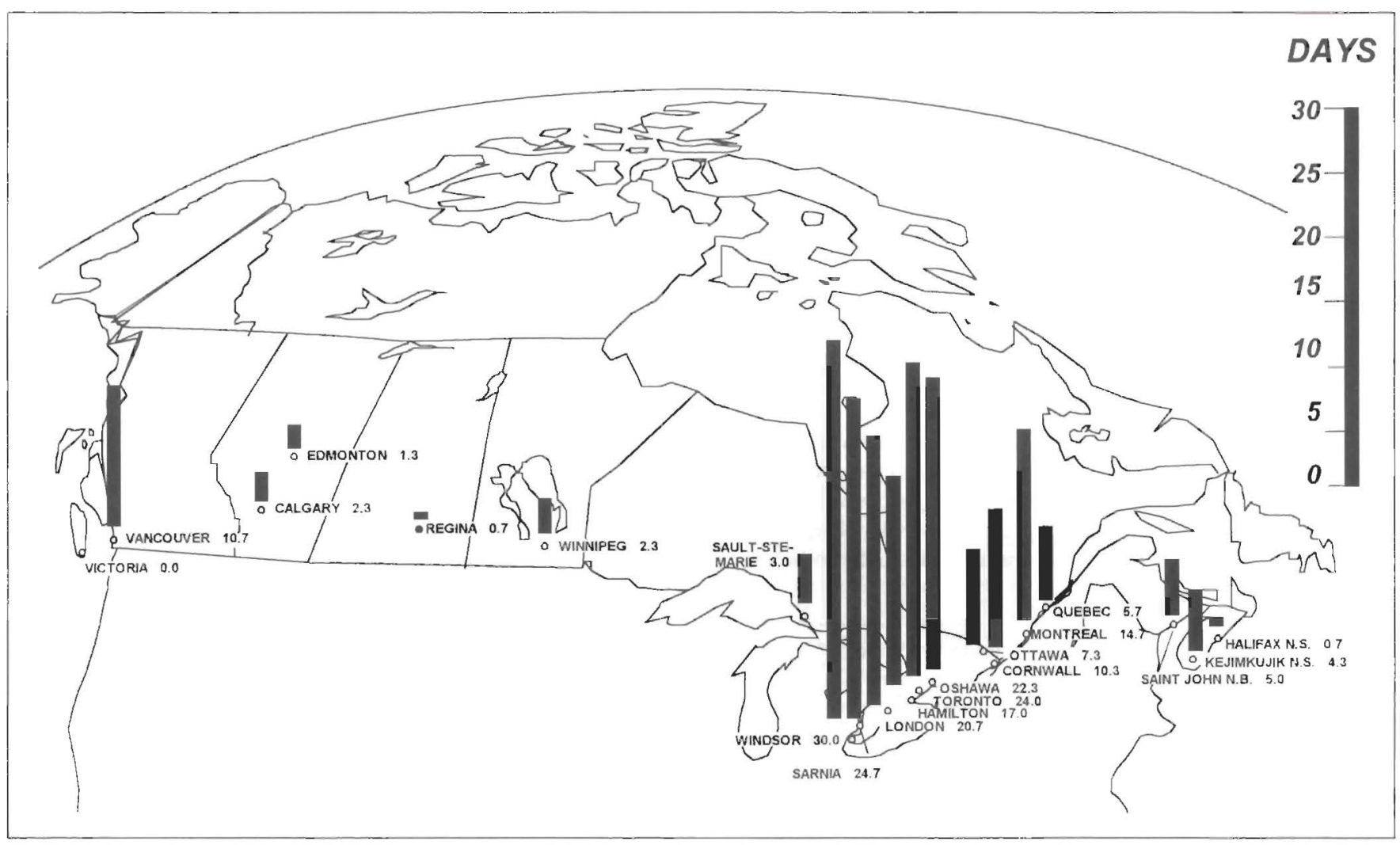

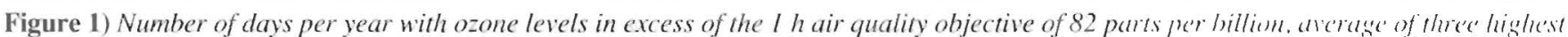
years 1983-1990 (Source: Environment Canada, 1994)

program, ground-level ozone forecasts are produced cooperatively by Environment Canada, the provincial ministries of environment and municipal air quality offices, based on meteorological and air monitoring data. Advisories are issued when $1 \mathrm{~h}$ maximum levels are forecasted to exceed a specified level, depending on the jurisdiction, but generally $82 \mathrm{ppb}$. They consist of an environmental message that describes the pollution sources that contribute to smog (chiefly automobile transport) and the need for the public to reduce its dependency on cars, as well as a health message that advises the public of possible health risks associated with smog exposure. The exact content of the messages is determined by provincial environmental and health authorities. In 1993, the first summer of the program's existence, four advisories were issued - two in Saint John and one each in southern Ontario and the Greater Vancouver Regional District. A similar number of advisories was issued in 1994. As seen in Figure 1, a significantly greater number of episodes of elevated groundlevel ozone concentrations has occurred in these areas in previous years.

\section{METHODS}

Health aspects of the advisory program were addressed for Health Canada and Environment Canada by two expert panels convened by the Institute of Environment and Health of McMaster University and the University of Toronto. The panels comprised individuals with experience in air pollution health research, public health, air pollution meteorology and measurement, and health care delivery. The chair and several panel members had independently conducted literature reviews before their participation in the panels and key references were provided to panel members in preparation for one-day meetings of each group. Each panel was asked Io define the health effects expected at levels of exposure given by the National Ambient Air Quality Objectives; to examinc a variety of issues related to communicating with the public about environmental health risks; and to draft health messages for the advisory program. Although under the Smog Advisory Program, advisories are issued only for groundlevel ozone, effects of airborne particles were also considered by the panels. While the same individual chaired both panels, great care was taken 10 allow each group scope to produce differing conclusions and recommendations. Nonetheless, a strong concurrence was noted between the findings of the two panels. Once the panels were completed, minutes of each panel as well as a synthesis were circulated to the panel members for comment and revision.

\section{PANEL FINDINGS}

The panels considered a variety of evidence on the relittionship between air pollution and health. This included laboratory studies, which have examined the pathophysiological mechanisms through which pollutants exert their effects: chamber studies, which have been used to measure various human health effects at controlled exposure levels; pincl studies, in which (for example) children attending summer 


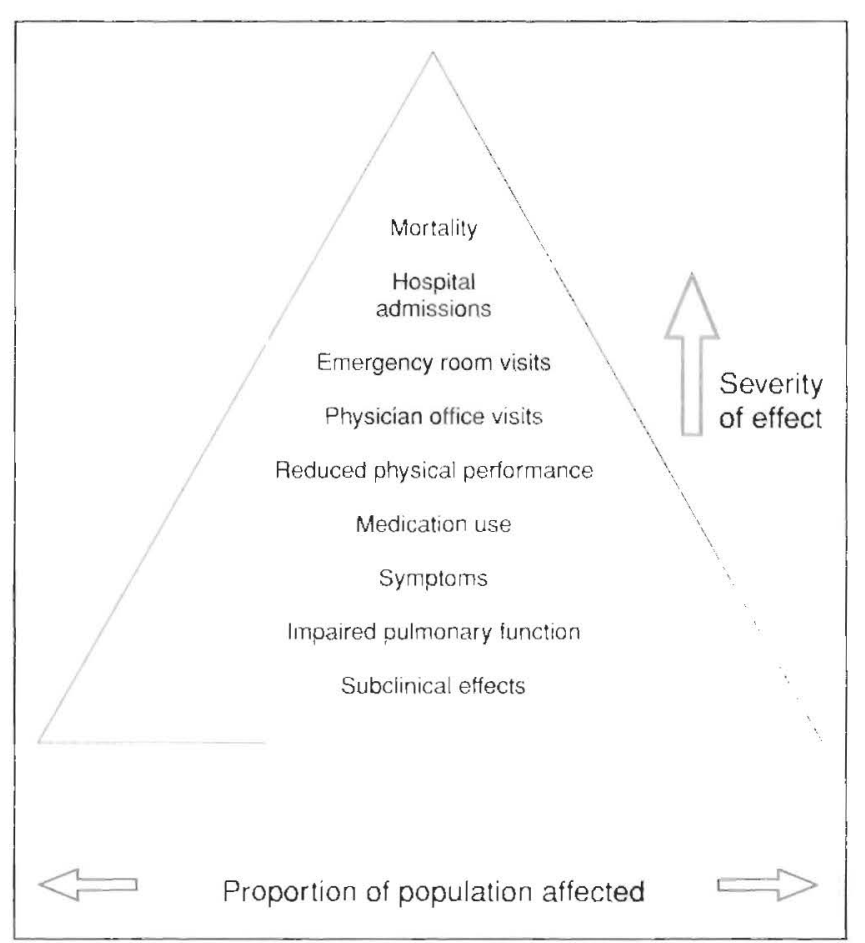

Figure 2) Schemalic represe'mation of the potential health effects of air pollution. Adapted with permission from the American Thoracic Society (9)

camp have been followed with respect to pulmonary function and symptoms in relation to ambient pollutant levels; and studies based on administrative data on emergency room visits, hospital admissions and mortality and their relationship to changing pollutant levels. It was noted that the latter "ecologic' studies have been criticized hecause they lack important data on individual exposure, and that in studics of exposurc to ambient pollution, it hats been difficult to separate the effects of individual pollutants. particularly ground-level orone and acid arerosols.

The pancls conceptualized the potential health effects of air pollution as occurring in a logical 'cascate' or 'pyramid", ranging from severe, uncommon events (eg, dcath) to mild. common effects (eg, eye, nose and throat irriation) and asymptomatic changes of unclear clinical signilicance (eg, small pulmonary function decrements and pulmonary inflammition) (9,10). Thus, while according to this model scvere health events precipitated by atr pollution would be rare, there is a potentially large overall impact on health and well-bcing (Figure 2).

With respect to ground-level ozone, the panels ficlt that current pathophysiological evidence suggested that ozone is associated with an inflammatory response manifested by increased arrway membrane permeability and bronchial hyperreactivity (1 1, 12). Some of the recent epidemiolonicial literature reviewed by the panels indicated that pulmonary function measures in children attending summer camp in southern Ontario were reduced on average by $3.5 \% 7 \%$ when I h alverage concentations of ground-level o/one reached $140 \mathrm{pph}(13)$, that approximately $5 \%$ of Ontario hospital admissions for respiratory disease may be attributable to elevated concentrations of ground-level orone $(4,14)$ (up 10 $15 \%$ in those under two years of age [in combination with sulphate particles] [4]), and that in Los Angeles the combinalion of ground-level ozone, nitrogen dioxide and temperature accounted for $4 \%$ of the day to day variability in mortality (excluding accidents and suicides) (15). Whether the effects observed in epidemiological studies can be directly attributed to inflammatory responses seen in laboratory studies is unclear. The evidence for chronic effects is also unclear. The panels concluded that there was some evidence that certain groups are more susceptible to the acute effects of groundlevel orone, either on the basis of increased sensitivity (the

TABLE 1

Expert panel summary of health effects of ground-level ozone

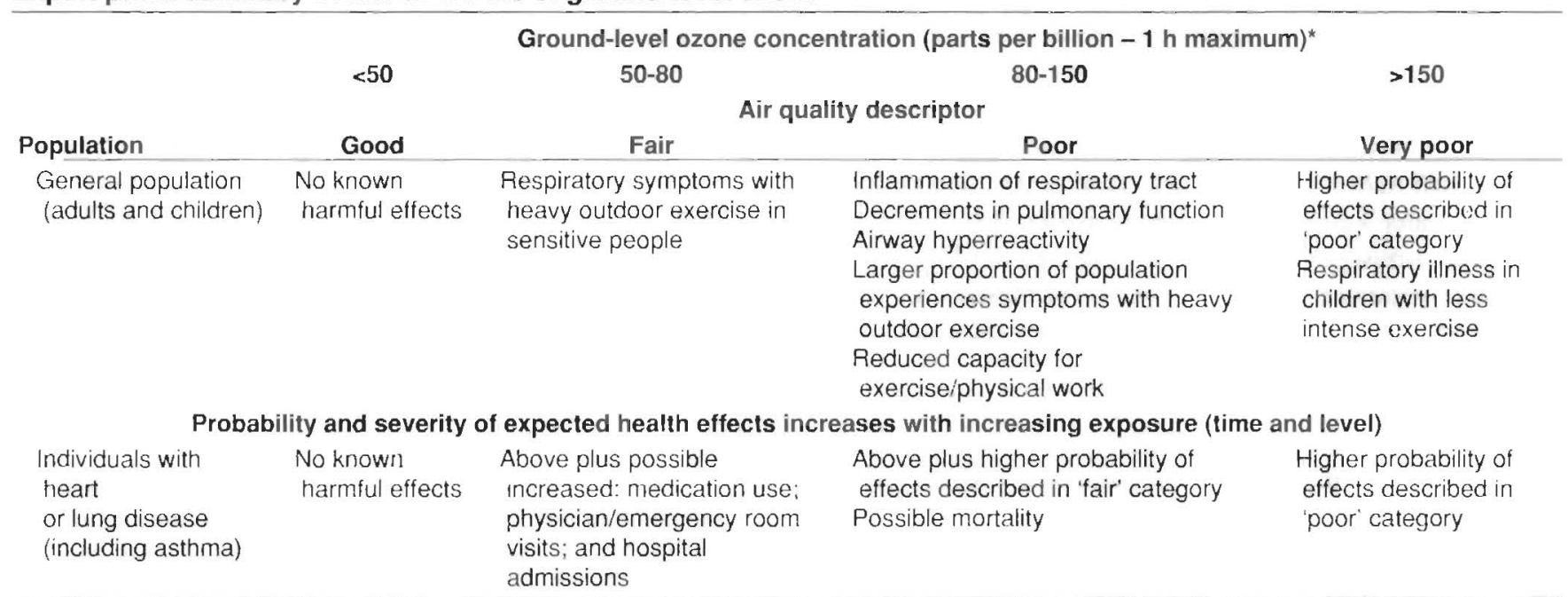

"50 ppb = Maximum desirable concentration: 80 (82) ppb = Maximum acceptable concentration: 150 ppb = Maximum tolerable concentration Source reference 1 
very young, the elderly, those with chronic cardiac or respi ratory disease) or increased exposure during outdoor activity (schoolchildren, joggers, cyclists and other athletes, and outdoor workers such as farm and construction workers). However, this was recognized as a controversial area. The panels differed in their interpretation of the evidence on the occurrence of harmful effects in the general population at levels below $80 \mathrm{ppb}$.

A synthesis of the effects identified by the panels at concentrations given by the National Ambient Air Quality Objectives is presented in Table 1. This table summarizes the current scientific evidence, weighing what the panels saw as the relative strength of the evidence for various effects at various levels. The contents of the table do not translate the evidence into appropriate messages for communicating with the general public.

Although the panels were not specifically asked to address the issue of whether there was a threshold concentration for ground-level ozone below which effects would not be expected, they were required to frame their findings according to the National Ambient Air Quality Objectives, which inevitably raised the threshold issue. There was little support among panel members for the concept of a threshold concentration for effects of ground-level ozone, which is reflected by their conclusion that the probability and severity of expected health effects increases with increasing exposure ( $\mathrm{Ta}$ ble 1). However, it was recognized that this was a separate issue from choosing an administrative threshold concentration (16) for the purposes of issuing advisories. The latter issue was felt to be more appropriately addressed by authorities in the individual regions where advisories are issued (as described earlier).

With respect to airbornc particles, the panels felt that the pathophysiological mechanism through which they exert their effects on respiratory health was not well understood. Some of the recent epidemiological literature reviewed by the panels (much of which originates in the United States) indicated that elevations of $\mathrm{PM}_{10}$ concentrations of approximately 100 to $150 \mu \mathrm{g} / \mathrm{m}^{3}$ are associated with reductions in peak expiratory flow of up to $6 \%(17,18)$, approximately sixfold increases in medication use among asthmatics (18), 1.5- to twofold increases in respiratory symptom reporting (17,18), 40\% increases in school absenteeism (19), statisticully significant increases in respiratory hospital admissions (20) and up to $16 \%$ increases in mortality (excluding accidents and suicide) (21). The panels concluded that groups with greatest susceptibility appear to be those with chronic cardiac and respiratory disease, although this was recognized as a controversial area. As was the case for ground-level ozone, although the panels were not specifically asked to address the question of the existence or level of a threshold concentration for the effects of airborne particles, the question again arose because the panel was required to frame its findings according to various levels of exposure as was done for ground-level ozone. There was little support among panel members for the concept of a threshold for the effects of airborne particles.
"Ground-level ozone, the major component of smog, is of primary concern because it is a powerful irritant and can have potentially harmful effects on the respiratory system. Symptoms are most likely to occur in individuals who are physically active outdoors. People with heart or lung disease, especially asthma, may experience a worsening of their condition."

Commonly reported symptoms include irritation of the nose and throat, cough, and chest tightness. Minimize your exposure by avoiding outdoor exercise particularly in the afternoon and early evening when ground-level ozone concentrations tend to be at their highest."

\section{"Children tend to be more sensitive than adults because they breathe faster and in the summer spend more time outdoors being physically active. Reduce your child's exposure by encouraging outdoor activities early in the day when pollutant levels are lower."}

Figure 3) Sample of public information messages made available by Health Canada to supplement Sino: Advisory Program messages. Source reference 22

\section{PANEL RECOMMENDATIONS}

While the panels made a number of wide-ranging recommendations, only those relating to the content of health messages and their implementation are summarized here.

With respect to the content of health messages, particular issues identified by the panels included the following: appropriate emphasis for 'diagnostic' versus 'prescriptive' messages (those that identify expected health effects versus those that recommend protective actions); identification of target groups; ensuring that messages accurately reflect the scientific evidence and do not unduly raise public concern; and selection of an appropriate threshold for the ground-level ozone advisory. In consultation with provincial public health authorities, it was strongly recommended that the health messages be diagnostic only, with the recommendation that more specific prescriptive advice be obtained from local public health authorities and/or personal health care providers familiar with the individual's clinical history.

With respect to implementation aspects of the advisory program, the panels recommended supplementary education strategies directed towards individuals at risk as well as parents, teachers, athletes, coaches, health professionals and public health officials, and identified the need for evaluation of the impact of the advisory program.

In response to these recommendations Health Canada has developed a series of supplementary public information messages, which have been made available to the public in both official languages through the media, physicians' offices, hospitals and parenting magazines (see Figure 3 for sample messages). In addition, Health Canada is collaborating with Environment Canada in conducting public surveys to evaluate various aspects of the advisory program, including awareness of advisories and advisory-related changes in behaviour. 


\section{CONCLUSIONS}

The expert panel process served as a rapid means of identifying and interpreting the evidence on health effects of ground-level ozone and airborne particles. Mounting evidence was identified linking elevated concentrations of these pollutants with a spectrum of harmful effects on health, and recommendations were made regarding effective communication with the public about these risks.

Note: The original report of the panels (reference 1), including a detailed reference list, as well as public information materials on various air pollutants, are available from the corresponding author.

\section{REFERENCES}

1. Pengelly LD, Taylor SM, Stieb D. Canadian Smog Advisory Health Matrices for Ozone and Suspended Particles, Final Report. Hamilton and Toronto: Institute of Environment and Health, prepared for Health and Welfare Canada Environmental Health Directorate, 1993.

2. World Health Organization, Regional Office for Europe: aculc effects on health of smog episodes. Report on a WHO meeting: 1990 Oct 30-Nov 2, 's Hertogenbosch, Netherlands. Copenhagen: WHO Regional Publications, European Series, No 43, 1992.

3. Lippman M. Health effects of ozone - a critical review. J Air Poll Control Assoc 1989;39:672-95.

4. Burnett RT, Dales R, Raizenne ME, et al. Effects of low ambient levels of ozone and sulfates on the frequency of respiratory admissions to Ontario hospitals. Environ Res 1994;65: 172-94.

5. Hilborn J, Still M. Canadian Perspectives on Air Pollution. Ottawa: Minister of Supply and Services Canada, 1990.

6. Spengler JD. Outdoor and indoor air pollution. In: Tarcher AB, ed. Principles and Practice of Environmental Medicine. New York: Plenum Medical Book Company, 1992:21-41.

7. Review of the national air quality standards for particulate matter: assessment of scientific and technical information. Report No EPA-450/5-82-001. Research Triangle Park: Strategies and Air Standards Division, Office of Air Quality Planning and Standards, US Environmental Protection Agency, 1982.

x. Dann T. PM 10 and $\mathrm{PM}_{2.5}$ Concentrations at Canadian Urban Sites: 1984-1993. Ottawa: Environment Canada, 1994.
9. American Thoracic Society, Guidelines as to what constitutes an adverse respiratory health effect, with special reference to epidemiologic studies of air pollution. Am Rev Respir Dis 1985;131:666-8.

I0. Bates DV. Health indices of the adverse effects of air pollution. The question of coherence. Environ Res 1992;59:336-49.

11. Crapo J, Miller FJ, Mossman B, Prior WA, Kiley JP. Relationship between acute inflammatory responses to air pollutants and chronic lung disease. Am Rev Respir Dis 1992; [45:1506-12.

12. Devlin RB, McDonnell WF, Mann R, et al. Fxposure of humans to ambient levels of ozone for 6.6 hours causes cellulat and biochemical changes in the lung. Am J Respir Cell Mol Biol 1991;4:72-81.

13. Raizenne ME, Bumett RT, Stern B, Franklin CA, Spengler JD). Acute lung function responses to ambient acid aerosol exposures in children. Environ Health Perspect 1989;79:179-85.

14. Bates DV, Sizto R. Air pollution and hospital admissions in Southern Ontario: the acid summer haze effect. Environ Res 1987; 43:317-31.

15. Kinney PL, Ozkaynak H. Associations of daily mortality and air pollution in Los Angeles County. Environ Res 1991;54:99-120.

16. Pengelly LD, Silverman FS, Taylor SM. A Hierarchy of Potential Health Effects From Air Pollution Exposure, Final Report. Hamilton and Toronto: Instituke of Environment and Health, 1994.

17. Pope CA, Dockery DW. Acute health effects of PMio pullution on symptomatic and asymptomatic children. Am Rev Respir Dis 1992;145:1123-8.

18. Pope CA, Dockery DW, Spengler JD, Raizenne ME. Respiratory health and $\mathrm{PM}_{10}$ pollution. A daily time series analysis. Am Rev Respir Dis 1991;144:668-74.

19. Ransom MR, Pope CA. Elementary school absences and PM ${ }_{10}$ pollution in Utah Valley. Environ Res 1992;58:204-19.

20. Pope CA. Respiratory hospital admissions associated with $\mathrm{PM}_{10}$ pollution in Utah, Salt Lake, and Cache Valleys. Arch Environ Health 1991;46:90-7.

21. Pope CA, Schwartz J, Ransom MR. Daily mortality and PM $\mathrm{M}_{[0}$ pollution in Utah Valley. Arch Environ Health 1992;47:2 I I-7.

22. Environment Canada, Health and Welfare Canada, Energy, Mines and Resources Canada, Canadian Council of Ministers of the Environment NOx/VOC Office. Air Care: A parents' Guide to Air Quality and Health. Today's Parent Group, 1993. 


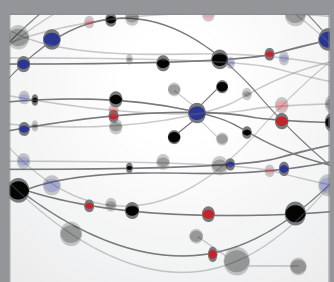

The Scientific World Journal
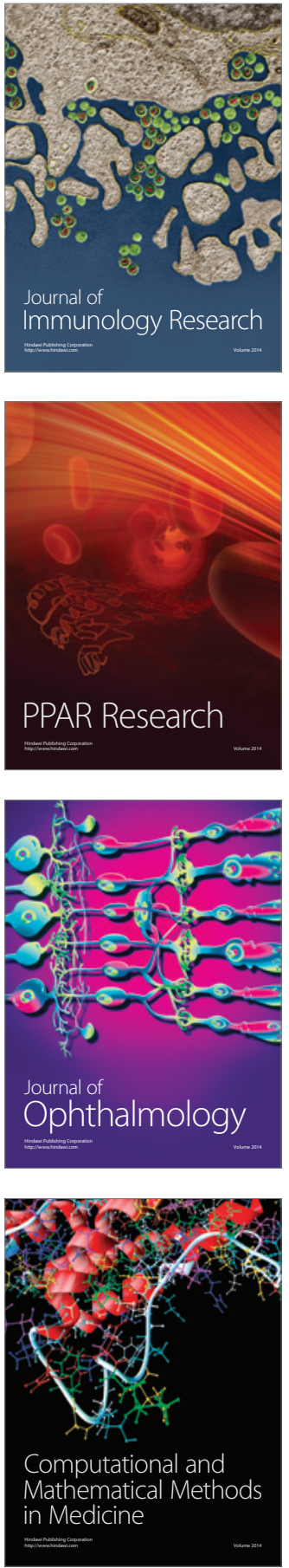

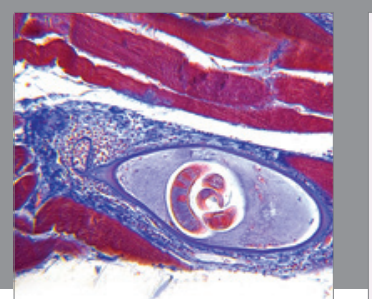

Gastroenterology Research and Practice

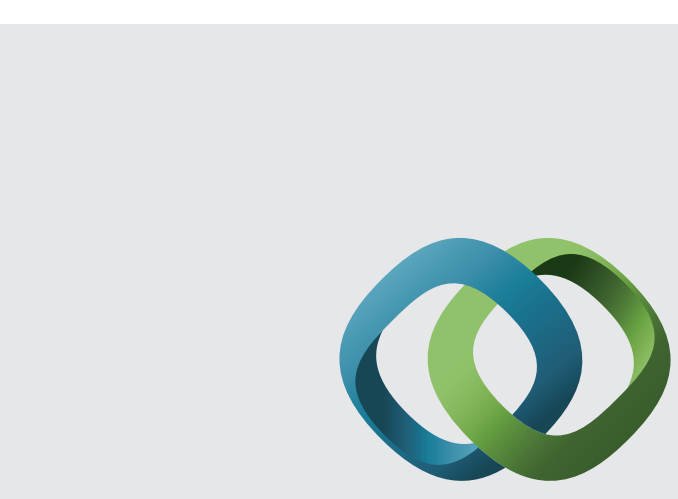

\section{Hindawi}

Submit your manuscripts at

http://www.hindawi.com
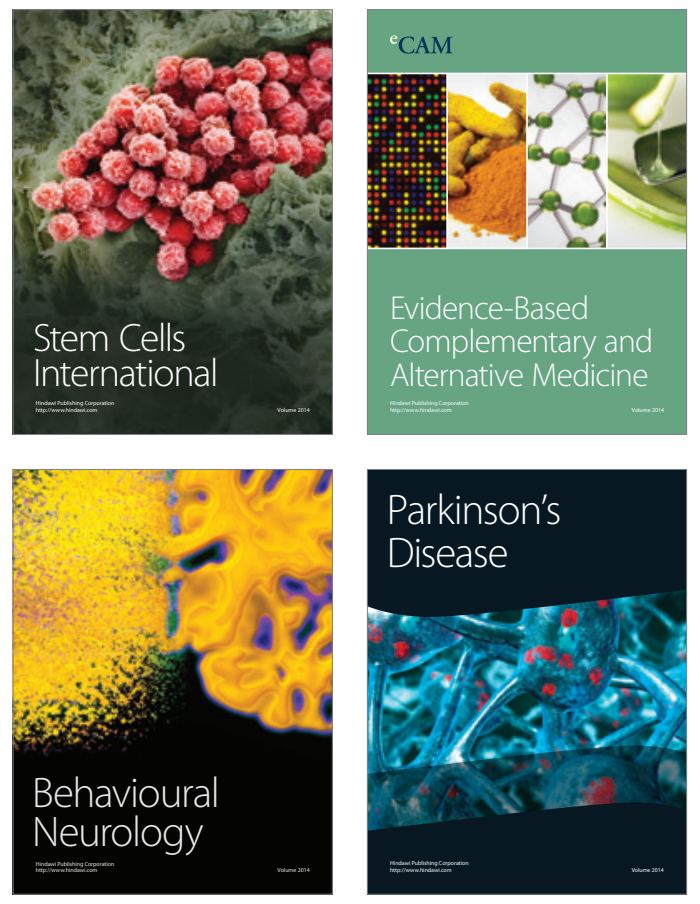
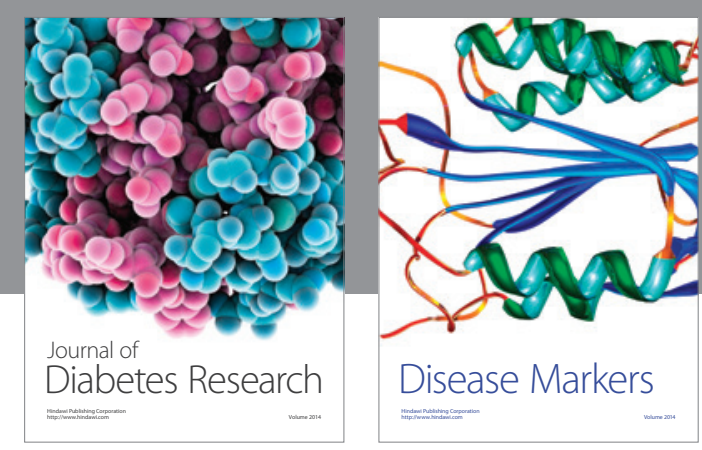

Disease Markers
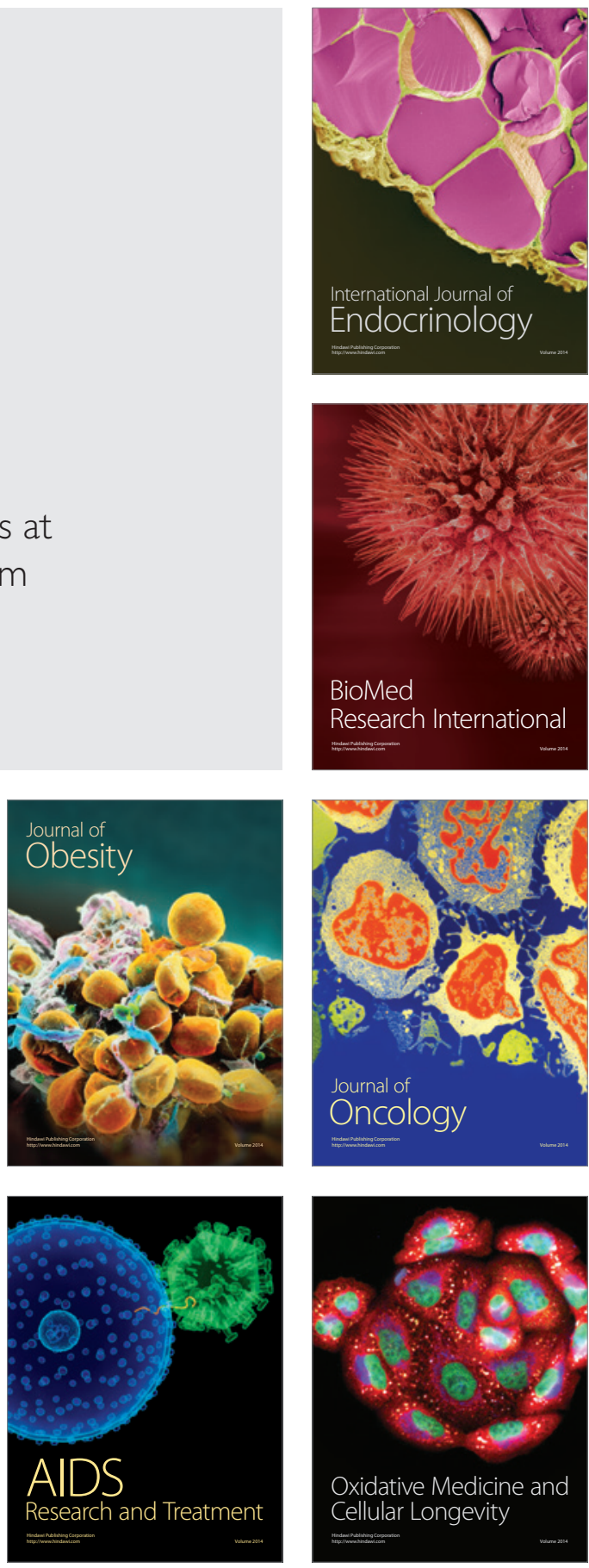